\title{
KAJIAN SIFAT FISIKA TANAH BEBERAPA PENGGUNAAN LAHAN DI BUKIT GAJABUIH KAWASAN HUTAN HUJ AN TROPIK GUNUNG GADUT PADANG
}

\author{
Yulnafatmawita, Utry Luki, dan Afri Yana \\ Laboratorium Fisika Tanah J urusan Tanah F akultas Pertanian U niversitas Andalas Padang
}

\begin{abstract}
Study about soil physical properties of Bukik Gajabuih Padang, the area receiving high annual rainfall $(>5000 \mathrm{~mm}$ ), was conducted at different land uses in 2006 . The objective of this research was to measure the change of soil physical properties as forest was cut down and converted into mixed perennial plant field and into bush land. The results showed that changing forest area into land use for mixed perennial trees for more than 50 years increased SOM content on the top $0-20 \mathrm{~cm}$, but decreased on the $20-40 \mathrm{~cm}$ layer. The highest SOM content was found under bush land. Therefore, the bulk densisty of the soil decreased from forest to mixed land use and to bush land. The opposite trend was found for total pores and permeability rate. While the plasticity index of the soil followed the clay percentage of the soil texture, it increased by increasing clay content of soil from forest into mixed field and bush land use.
\end{abstract}

\section{Key Words: Land U se Change, Soil Organic Carbon, Soil Physical Properties}

\section{PENDAHULUAN}

Sifat fisika tanah merupakan kunci penentu kualitas suatu lahan dan lingkungan. Lahan dengan sifat fisika yang baik akan memberikan kualitas lingkungan yang prima. Demikian juga rusaknya suatu lahan berkaitan erat dengan kondisi fisik tanah yang jelek. Di samping itu, perbaikan sifat fisika tanah yang mengalami kerusakan membutuhkan biaya yang tinggi dan waktu yang lama. Faktor ini juga yang mendasari kenapa sifat fisika tanah diambil sebagai pertimbangan pertama dalam menetapkan suatu lahan untuk pertanian. Oleh sebab itu, pengelolaan sifat fisika tanah yang sesuai dengan kaidah konservasi sangat penting untuk menjaga kesinambungan sumber daya lahan yang berwawasan lingkungan.

Diantara sifat fisika tanah yang sangat mempengaruhi kualitas tanah yaitu struktur tanah. Hal ini disebabkan karena struktur tanah baik secara lansung maupun tidak lansung mempengaruhi sifat fisika tanah lainnya. Struktur mempengaruhi porositas, retensi dan transmisi air tanah, jenis dan saat pengolahan yang tepat, serta beberapa sifat tanah lainnya. Akan tetapi, struktur tanah bersifat dinamis. Tidak seperti tekstur, struktur sangat mudah berubah dari waktu ke waktu dan dengan energi input yang diberikan, seperti akibat pengolahan tanah atau pukulan butir hujan, dan sebagainya. Tingkat perubahan struktur tanah ini berhubungan dengan perubahan yang terjadi pada kandungan bahan organik tanah tersebut.

Perubahan status bahan organik suatu tanah yang akhirnya akan mengubah sifat fisika tanahnya bisa terjadi akibat alih fungsi lahan. Hal ini bukan saja disebabkan oleh berubahnya jenis dan jumlah sumber BO yang masuk ke dalam tanah, tetapi dengan pengolahan tanah juga mengakibatkan meningkatnya oksidasi BO tanah. Terdekomposisinya BO menyebabkan berkurangnya kandungan BO tanah. Kehilangan BO tanah akan mengurangi kemantapan aggregat (Yulnafatmawita, 2005; Oades et al., 1984; Chappel et al., 1999), dan bahkan bila kandungan BO tanah di bawah batas kritis, maka aggregat tanah akan hancur menjadi aggregat kecil (mikro), dan sangat rapuh. Selanjutnya, bila hari hujan, oleh tumbukan (energi kinetik = Ek) butir hujan aggregat akan hancur menjadi butir tunggal atau terdispersi. Kondisi demikian akan mengakibatkan penyumbatan pori tanah, penurunan kapasitas infiltrasi, peningkatan laju runoff, dan akhirnya menimbulkan erosi bila hujan berlanjut. Jadi, disamping perbaikan struktur tanah, 
BO secara tidak lansung juga meningkatkan infiltrasi tanah (Suriadikarta et al., 2005). Albiach et al. (2001) menyarankan bahwa BO dan karbohidrat merupakan predictor terbaik bagi stabilitas aggregate tanah.

Daerah Bukit Gajabuih terletak di kawasan hutan hujan tropik kaki gunung Gadut Padang yang terletak di kota Padang bagian timur yaitu sekitar $18 \mathrm{~km}$ dari pusat kota, tercatat sebagai penerima curah hujan tahunan $\pm 6500 \mathrm{~mm}$, tertinggi di dunia (Rasyidin dan Wakatsuki, 1994). Daerah ini merupakan hulu dari dua sungai utama, Batang Arau dan Batang Kuranji, yang melintasi kota Padang yang menjadi sumber perairan kota. Daerah ini seharusnya tetap dihutankan untuk menjaga kelestarian sumber daya alamnya dan lingkungan daerah alirannya, yaitu Kota Padang dan sekitarnya.

Akan tetapi, penduduk yang tinggal di dekat kawasan Bukik Gajabuih ini sudah mulai menebang kayu secara liar (Illegal logging). Lahan bekas penebangan sebagian dijadikan kebun campuran oleh penduduk setempat, terutama yang terdapat di kakinya. Kebun campuran ini sebagian ada yang sudah lama diusahakan, tetapi juga ada yang baru ditanami. Pada bagian yang agak tinggi atau pada lereng yang lebih curam, seperti pada pinggang dan puncak bukit, lahan yang sudah ditebang ditinggalkan saja menjadi semak belukar.

Selama 5 tahun terakhir illegal logging sangat marak terjadi. Bila hal ini tidak diantisipasi dari sekarang, maka musibah banjir di musim hujan dan kekeringan di musim kemarau seperti dialami oleh daerah lain di Indonesia tidak lama lagi akan sampai di kota Padang dan sekitarnya. Oleh sebab itu, perlu diketahui apakah sudah terjadi penurunan sifat fisika tanah akibat penebangan hutan tersebut, serta penggunaan lahan yang bagaimana yang sangat mungkin memicu terjadinya degradasi lahan. Tujuan dilakukannya penelitian ini adalah untuk menganalisis beberapa sifat fisika tanah pada beberapa penggunaan lahan dan membandingkannya dengan sifat fisika lahan hutan dalam rangka memperkirakan tingkat penurunan kualitas tanah akibat alih fungsi lahan pada daerah kawasan hutan hujan tropik Bukit Gajabuih Padang.

\section{METODE PENELITIAN}

Penelitian ini dilaksanakan dari bulan Juni sampai November 2006 dilapangan dan dilaboratorium (Fakultas Pertanian Unand). Penelitian ini dilakukan dalam 3 tahap : (1) tahap persiapan dan survai pendahuluan (2) survai utama untuk pengambilan contoh tanah (3) Analisis laboratorium dan pembuatan laporan.

\section{Tahap Persiapan dan Survai Pendahuluan}

Pada tahap persiapan ini dilakukan pengumpulan data sekunder mengenai lokasi yang akan dilakukan penelitian. Data-data tersebut meliputi : Peta jenis tanah, peta penggunaan lahan, dan peta topografi. Survai pendahuluan dilakukan guna mengetahui keadaan lokasi penelitian dilapangan dan menetapkan titik-titik pengambilan sampel.

\section{Survai Utama dan Pengambilan Sampel Tanah}

Pengambilan contoh tanah dilakukan pada 3 tipe penggunaan lahan, yaitu hutan, kebun campuran, dan semak belukar. Masing-masing penggunaan lahan diambil 3 - 4 ulangan tergantung luas area masingmasing lahan.

\section{Analisis laboratorium dan pembuatan laporan}

Analisis tanah yang dilakukan diantaranya: tekstur (metoda pipet dan ayakan), BV dan TRP (metoda gravimetri), distribusi ukuran pori (\% PDL, \% PDC, \% PAT) dengan metoda kertas saring, permeabilitas jenuh (hukum Darcy), bahan organik tanah (Walkley dan Black), dan indeks plastisitas tanah (Atterberg). Data yang diperoleh dinilai berdasarkan kriteria sifat fisika tanah.

HASIL DAN PEMBAHASAN 
Berdasarkan hasil pengamatan di lapangan, area di kawasan hutan hujan tropic Bukit Gajabuih sudah banyak yang ditebang. Pada bagian yang agak datar ( $\pm 3-8 \%$ lereng) di kaki Bukit Gajabuih ini umumnya sudah dibuka sekitar > 30 tahun yang lalu dan dijadikan kebun campuran (KC). Tanaman utama pada kebun ini adalah durian, manggis. Sebagian lagi masih ada yang baru ditanam untuk tanaman kopi dan cokelat oleh

penduduk setempat. Daerah yang ditanami tanaman tua ini ditumbuhi oleh tanaman bawah (under storey) yang berperan sebagai cover crop pada permukaan lahannya.

Kawasan hutan terdapat pada puncak bukit bagian timur yang punya ketinggian \pm $595 \mathrm{~m}$ dpl. Di daerah ini, cahaya matahari tidak sampai menembus kanopi tanaman sehingga lebih gelap dan lantai hutan bersih dari tanaman penutup tanah tetapi ditutupi oleh serasah. Sedangkan pada sisi bagian barat bukit dari tengah sampai puncak sudah tidak ada hutannya, melainkan ditumbuhi oleh semak belukar. Bahkan pada sebagian area dijadikan lahan pertanaman tanaman semusim.

Menurut Wakatsuki et al (1986) ordo tanah di pucak bukit Gajabuih bagian barat termasuk Inceptsols dengan great group Oxic-dystropept. Berdasarkan analisis tanah yang dilakukan di laboratorium terhadap beberapa sifat fisika tanah di kawasan Bukit Gajabuih Padang ini maka didapat hasil seperti yang terdapat pada Tabel 1. Dari Tabel 1 terlihat bahwa secara umum terjadi perbedaan sifat fisika Tanah antara 3 penggunaan lahan. Diantara sifat fisika yang diamati yaitu tekstur, BV, TRP, permabilitas, indeks plastisitas, dan bahan organik tanah. Masing-masing sifat tanah ditampilkan dalam bentuk grafik.

\section{Tekstur Tanah}

Dari Tabel 1 terlihat bahwa di daerah bukik Gajabuih kawasan gunung Gadut Padang mempunyai tekstur agak kasar atau dengan kelas tekstur (menurut Soil taxonomy USDA, 1975) lempung berdebu pada lokasi yang ditumbuhi tanaman tua atau kebun campuran dan vegetasi hutan. Tanah pada umumnya juga mempunyai solum yang dangkal. Dari hasil penelitian (Rasyidin, 1986), tanah ini termasuk ordo Inceptisols yaitu tanah yang sedang mengalami perkembangan, jadi bahan mineral tanah belum terlapuk sempurna. Hal ini terbukti dengan banyaknya batu ditemukan pada lapisan 0-40 cm saat survai lapangan. Akan tetapi, pada daerah yang ditumbuhi semak belukar mempunyai tekstur liat baik pada lapisan $0-20 \mathrm{~cm}$ maupun pada lapisan 20-40 cm. Diperkirakan tanah ini tidak lagi termasuk ordo Inceptisols, karena dari pengamatan lapangan area ini mempunyai tanah yang bersolum dalam dan tidak terdapat batuan pada solum tanah.

\section{Bahan Organik Tanah}

Secara umum kandungan bahan organic tanah lapisan atas $(0-10 \mathrm{~cm})$ lebih tinggi dari kandungan bahan organic di lapisan 20-40 cm (Gambar 1) pada semua penggunaan lahan. Hal ini bias dimaklumi karena lapisan atas akan menerima bahan organic segar yang lebih banyak dari bagian tanaman yang mati diatas permukaan tanah seperti serasah atau ranting yang patah, dan sebagainya. Sedangkan lapisan yang lebih dalam hanya akan menerima hanyutan bahan organik dari lapisan atas serta eksudat atau akar dan jasad hidup yang sudah mati. Jasad hidup dan akar tanaman ini jumlahnya lebih kecil dibanding sumber bahan organic di permukaan.

Selanjutnya, terlihat perbedaan kandungan bahan organic dari beberapa penggunaan lahan. Pada lapisan $0-20 \mathrm{~cm}$ kandungan bahan organik dengan vegetasi semak belukar (SB) lebih tinggi dari yang ditutupi hutan, tetapi pada lapisan $20-40 \mathrm{~cm}$ kandungan BO hampir sama antara kedua penggunaan lahan ini. Rendahnya kandungan BO pada lapisan 0-20 cm hutan disebabkan karena rendahnya tingkat pelapukan yang terjadi pada lantai hutan. Lantai hutan yang tidak mendapatkan cahaya matahari, bersuhu lebih rendah dibanding kebun campuran dan semak belukar, sehingga aktifitas mikroba juga rendah untuk merombak BO segar menjadi BO tanah. Di samping itu, BO yang ada di permukaan tanah berpeluang tercuci 
Tabel 1. Hasil analisis sifat fisika Tanah pada beberapa penggunaan lahan di kawasan hutan hujan tropik super basah Bukit Gajabuih Padang

\begin{tabular}{l}
\hline Penggunaan lahan \\
\cline { 2 - 6 }
\end{tabular}

Kedalaman $20-40 \mathrm{~cm}$

\begin{tabular}{l|c|c|c|c|c|c|c|c|c|c|c|c|c|c|}
\hline Hutan & 27.6 & 57.9 & 14.5 & $\begin{array}{c}\text { Lempung } \\
\text { berdebu }\end{array}$ & $1.04(\mathrm{~s})$ & $59.4(\mathrm{~s})$ & $4.0(\mathrm{r})$ & 34.1 & 20.1 & 17.5 & 7.0 & 8.7 \\
\hline Kebun Campuran & 21.4 & 57.7 & 20.9 & $\begin{array}{c}\text { Lempung } \\
\text { berdebu }\end{array}$ & $0.81(\mathrm{~s})$ & $68.4(\mathrm{~s})$ & $3.4(\mathrm{r})$ & 10.0 & 21.1 & 23.5 & 27.6 & 15.6 \\
\hline Semak Belukar & 6.4 & 21.7 & 71.8 & Liat & $0.79(\mathrm{~s})$ & $69.3(\mathrm{~s})$ & $3.5(\mathrm{r})$ & 1.7 & 24.0 & 18.7 & 10.8 & 11.5 \\
\hline
\end{tabular}

\section{Keterangan:}

$\mathrm{S}=$ sedang

$\mathrm{R}=$ rendah

$\mathrm{T}=$ tinggi 
(leached) ke lapisan bawah dalam profil tanah akibat tekstur tanah yang kasar. Oleh sebab itu, kemungkinan ini juga yang menyebabkan tingginya kandungan BO tanah hutan pada ke dalaman $20-40 \mathrm{~cm}$, di samping tingginya density perakaran tanaman pada lapisan ini yang akan menyumbang BO tanah.

\section{Bahan Organik Tanah}

Secara umum kandungan bahan organic tanah lapisan atas $(0-10 \mathrm{~cm})$ lebih tinggi dari kandungan bahan organic di lapisan 20-40 cm (Gambar 1) pada semua penggunaan lahan. Hal ini bias dimaklumi karena lapisan atas akan menerima bahan organic segar yang lebih banyak dari bagian tanaman yang mati diatas permukaan tanah seperti serasah atau ranting yang patah, dan sebagainya. Sedangkan lapisan yang lebih dalam hanya akan menerima hanyutan bahan organik dari lapisan atas serta eksudat atau akar dan jasad hidup yang sudah mati. Jasad hidup dan akar tanaman ini jumlahnya lebih kecil dibanding sumber bahan organic di permukaan.Selanjutnya, terlihat perbedaan kandungan bahan organic dari beberapa penggunaan lahan. Pada lapisan $0-20 \mathrm{~cm}$ kandungan bahan organic dengan vegetasi semak belukar (SB) lebih tinggi dari yang ditutupi hutan, tetapi pada lapisan $20-40 \mathrm{~cm}$ kandungan BO hampir sama antara kedua penggunaan lahan ini. Rendahnya kandungan BO pada lapisan 0-20 cm hutan disebabkan karena rendahnya tingkat pelapukan yang terjadi pada lantai hutan. Lantai hutan yang tidak mendapatkan cahaya matahari, bersuhu lebih rendah dibanding kebun campuran dan semak belukar, sehingga aktifitas mikroba juga rendah untuk merombak $\mathrm{BO}$ segar menjadi BO tanah. Di samping itu, BO yang ada di permukaan tanah berpeluang tercuci (leached) ke lapisan bawah dalam profil tanah akibat tekstur tanah yang kasar. Oleh sebab itu, kemungkinan ini juga yang menyebabkan tingginya kandungan BO tanah hutan pada ke dalaman $20-40 \mathrm{~cm}$, di samping tingginya density perakaran tanaman pada lapisan ini yang akan menyumbang $\mathrm{BO}$ tanah.
Kandungan $\mathrm{BO}$ yang ditanami tanaman tua $(\mathrm{KC})$ lebih tinggi dibanding yang ditumbuhi hutan pada lapisan permukaan tanah (0-20 $\mathrm{cm})$. Hal ini disebakan oleh banyaknya cover crop yang tumbuh (tanaman siklus pendek) yang cepat menyumbangkan BO nya ke dalam tanah. Tambahan lagi, tingkat dekomposisi BO di lokasi ini lebih tinggi dibanding di bawah hutan, akibat matahari masih bisa menembus sampai ke bawah diantara tanaman. Hal yang sama juga ditemukan oleh Yulnafatmawita et al (belum dipublikasi), bahwa kandungan BO tanah dengan penggunaan lahan hutan lebih rendah dibanding lahan kebun campuran di sub DAS Sumpur bagian hulu.

Pada umumnya kanopi tanaman pada lahan yang dikebunkan tidak serapat pada lahan hutan. Akan tetapi, kandungan BO tanahnya bervariasi dari satu lokasi ke lokasi lain. Hal ini disebabkan oleh tingkat atau intensitas penggunaan lahan oleh penduduk. Lahan yang dekat ke pemukiman penduduk juga diolah untuk tanaman semusim disamping untuk tanaman tua, sehingga kandungan bahan organiknya jadi menurun. Hal ini disebabkan karena meningkatnya laju dekomposisi bahan organik setelah pengolahan tanah (House et al, 1984). Sedangkan kandungan BO tanah lapisan 20$40 \mathrm{~cm}$ disebabkan oleh rendahnya jumlah (\%-tase) perakaran tanaman di zona ini dibanding dengan hutan.

Tingginya kandungan $\mathrm{BO}$ tanah pada lahan yang ditumbuhi semak belukar disebabkan oleh tingginya produksi BO akibat pendeknya siklus tanaman yang tumbuh. Vegetasi yang tumbuh pada lahan ini diantaranya krinyuh (C..odorata), melastoma, sirih, pimping, paku-pakuan, dan juga kacang-kacangan. Di samping itu, dengan suhu yang cukup tinggi akibat cahaya matahari yang cukup diterima aktifitas mikroba perombak juga tinggi. Tingginya aktifitas mikroba terbukti dengan kurangnya jumlah serasah yang terdapat di permukaan lahan ini dibanding di bawah vegetasi hutan dan kebun campuran. Akan tetapi, kandungan BO tanah bagian bawah lebih rendah. Hal ini disebabkan karena perakaran tanaman yang tumbuh disini pada umumnya terdapat pada lapisan $0-20 \mathrm{~cm}$, disamping pergerakan $\mathrm{BO}$ tanah ke bagian 


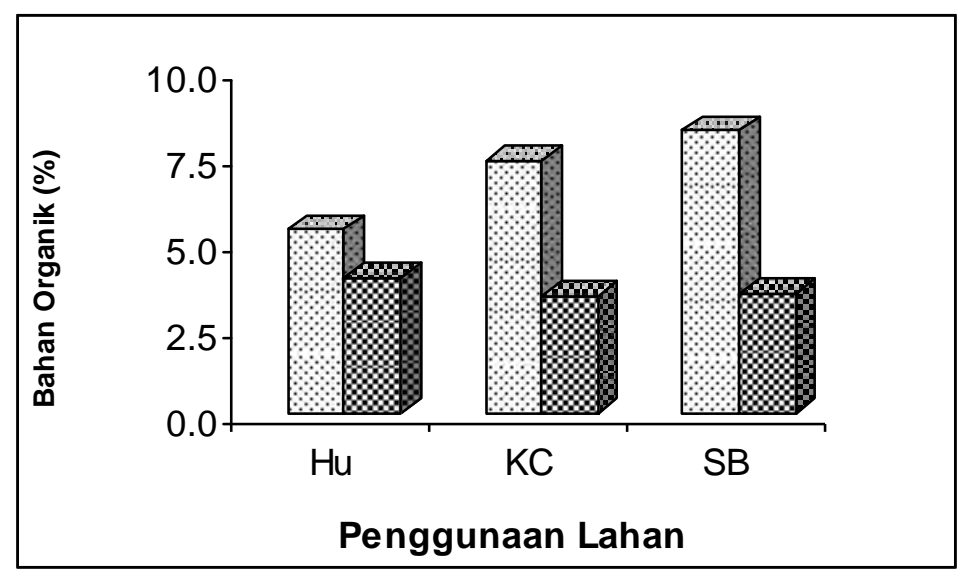

Gambar 1. Kandungan bahan organik (BO) tanah di kawasan Bukik Gajabuih G. Gadut Padang pada beberapapenggunaan lahan

bawah juga rendah akibat tekstur tanah yang berliat berat $( \pm 78 \%)$.

Di daerah sedang Australia, Yulnafatmawita (2004) mendapatkan penurunan kadar C-organik tanah Oxisol (Ferrosol) Queensland dari 6.9\% pada hutan hujan tropis menjadi $5.6 \%$ pada padang rumput (setelah \pm 100 tahun sejak hutan ditebang), di bawah curah hujan tahunan $\pm 1900 \mathrm{~mm}$. Pada tanah Vertisol Goondiwindi, Qld, dia juga mendeterminasi adanya kehilangan $0.8 \%$ C-organik akibat perubahan hutan Brigalow (Acasia) (Corganik $=2.0 \%$ ) menjadi lahan pertanian tanaman semusim yang diolah sekali setahun $(\mathrm{C}$-organik $=1.2 \%)$, dibawah kondisi semi arid (curah hujan tahunan $\pm 700 \mathrm{~mm}$ ). Sedangkan di daerah yang lebih kering (di pedalaman NSW, dengan curah hujan \pm 479 $\mathrm{mm}$ ), diidentifikasi terjadinya penurunan kadar C-organik Alfisol (Red Brown Earth) akibat perubahan penggunaan lahan dari ekosistem alami (semak-semak) dengan Corganik $=2.0 \%$ kepada lahan pertanian yang diolah secara konservasi dengan C-Organik $=1.7 \%$, dan kepada lahan pertanian yang diolah secara konvensional dan dirotasi antara tanaman dan bera $(\mathrm{C}$-organik $=1.3 \%)$. Bahkan Veldkamp (1994) pernah mendapatkan $50 \%$ penurunan kadar bahan organik tanah Andosols setelah dikonversi dari hutan menjadi pasture, walaupun bahan organiknya distabilisasi oleh adanya asosiasi bahan organik dengan seskuioksida.
3. Berat Volume (BV) dan Total Ruang Pori (TRP) Tanah

Pada Gambar 2 dilukiskan kondisi kerapatan isi atau BV di kawasan Bukik Gajabuih G.Gadut dengan beberapa penggunaan lahan. Pada umumnya, tanah di daerah tersebut mempunyai BV yang termasuk kriteria sedang. Hal ini didukung oleh kandungan bahan organic yang didominasi oleh berkriteria sedang, tinggi, dan sebagian rendah. Bahan organic diketahui mempengaruhi secara lansung $\mathrm{BV}$, kandungan bahan organic yang tinggi akan menurunkan nilai BV.

Bila dibandingkan antara kedua lapisan, maka BV di lapisan bawah (20-40 $\mathrm{cm})$ lebh tinggi dari di lapisan atasnya (0-20 $\mathrm{cm})$. Hal ini sangat berkaitan erat dengan kandungan bahan organic tanah, dimana lapisan atas mempunyai kandungan bahan organic yang lebih tinggi dari lapisan di bawahnya (Tabel 1). Di samping itu, tekstur yang lebih kasar dan tingginya prosentase bahan kasar atau terdapatnya bahan induk tanah ataupun kerekel pada lapisan tanah atas menyebabkan tingginya $\mathrm{BV}$ tanah di bawah hutan.

Berat volume tanah lapisan atas (0-20 $\mathrm{cm}$ ) yang lebih rendah berarti rendahnya jumlah masa tanah persatuan volume tanah pada lapisan tersebut dibanding lapisan 20$40 \mathrm{~cm}$. Hal ini berarti, prosentase rongga atau pori yang ada dalam tanah lapisan atas 


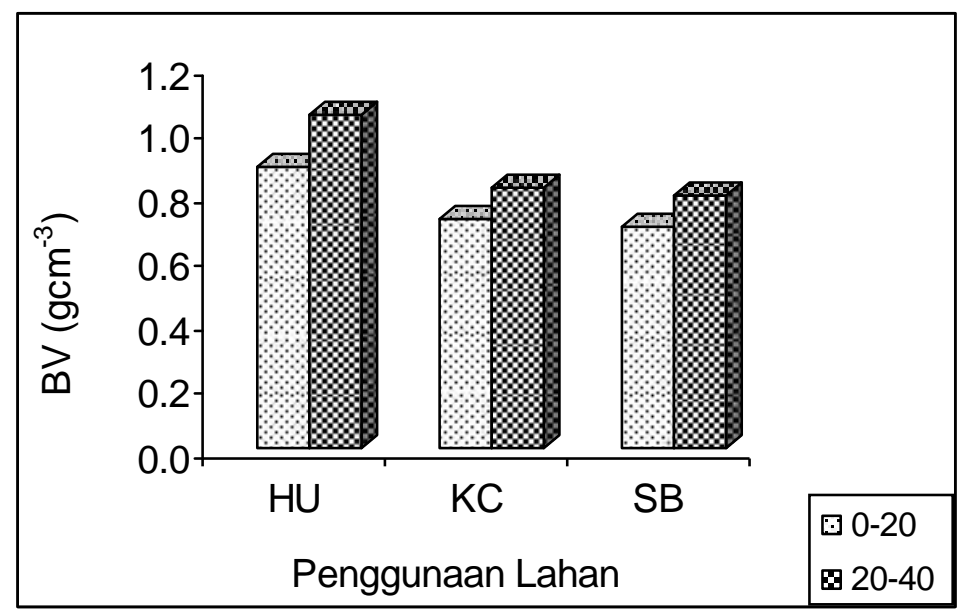

Gambar 2. Nilai bobot volume (BV) tanah di kawasan Bukik Gajabuih G. Gadut Padang pada beberapapenggunaan lahan

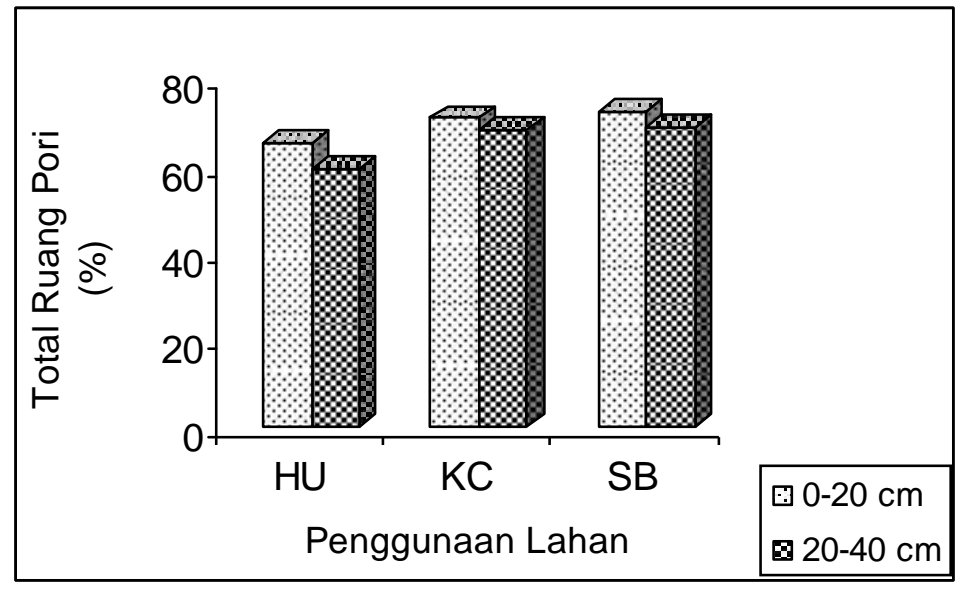

Gambar 3. Nilai total ruang pori (TRP) tanah di kawasan Bukik Gajabuih G. Gadut Padang pada beberapa penggunaan lahan

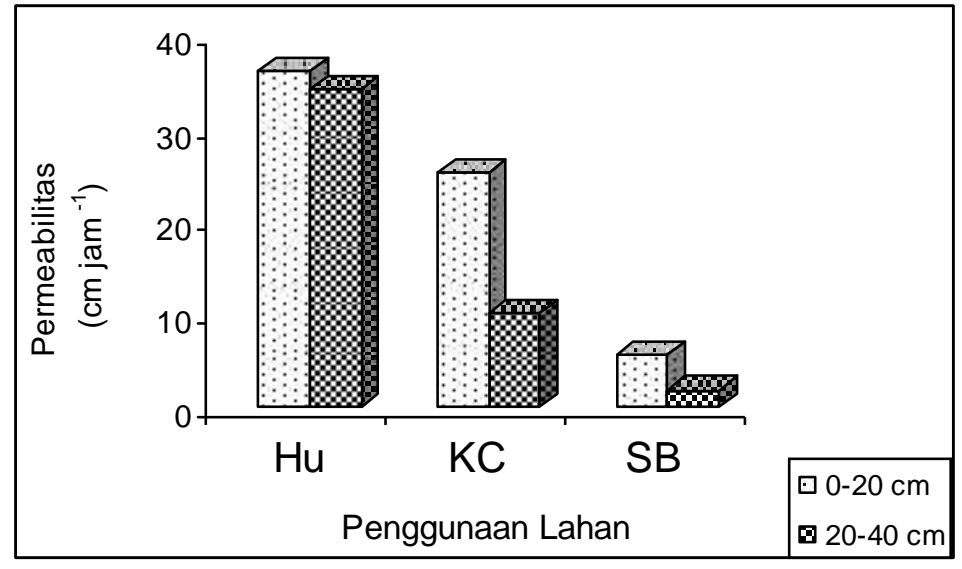

Gambar 4. Permeabilitas tanah beberapa penggunaan lahan di Bukik Gajabuih G. Gadut Padang 
lebih tinggi dari lapisan 20-40 cm. Walaupun ada kecendrungan peningkatan BV (Gambar 2) atau penurunan TRP (Gambar 3) dari lahan yang ditumbuhi semak belukar menjadi kebun campuran dan hutan, ataupun dari lapisan 0-20 ke 20-40 $\mathrm{cm}$, menurut kriteria semuanya termasuk sedang.

\section{Permeabilitas}

Dari Gambar 4 terlihat bahwa permeabilitas tanah lapisan atas jauh lebih tinggi dari lapisan bawah, yang berarti bahwa lapisan atas lebih poros dari lapisan bawah. Hal ini bisa dijelaskan dengan kadar bahan organic dan TRP. Tanah lapisan atas yang mempunyai kadar bahan organic dan TRP yang tinggi berati lebih poros dari lapisan bawah yang mempunyai kandungan bahan organic rendah. Tanah dengan kandungan BO yang tinggi akan mempunyai prosentase ruang pori makro yang lebih tinggi. Semakin tingg jumlah pori makro tanah makin semakin mudah tanah melewatkan air dalam keadaan jenuh atau semakin tinggi laju permeabilitasnya.

$$
\text { Bila dibandingkan diantara }
$$

penggunaan lahan, maka lahan hutan mempunyai nilai permeabilitas yang lebih tinggi dibanding lahan yang ditanami tanaman tua (KB) dan ataupun semak belukar (SB). Hal ini disebabkan oleh distribusi partikel atau tekstur tanah diantara penggunaan lahan. Tanah dengan fraksi kasar yang tinggi akan mempunyai prosentase pori makro yang lebih tinggi, sehingga akan lebih poros. Tanah di bawah hutan memiliki fraksi kasar lebih tinggi dibanding tanah di bawah kebun campuran, walaupun masih tergolong pada tekstur lempung berdebu (Tabel 1).

Laju permeabilitas tanah dibawah semak belukar jauh lebih kecil dibanding tanah hutan dan kebun campuran. Hal ini disebabkan oleh kandungan bahan halus, liat, tanah ini jauh lebih tinggi dari lahan lainnya. Tanah dengan kandungan liat yang tinggi akan mempunyai TRP yang tinggi, tetapi didominasi oleh pori berukuran kecil. Pada kondisi jenuh tanah berliat mempunyai kemampuan rendah untuk melewatkan air. Jadi, berdasarkan Tabel 1 dapat disimpulkan bahwa permeabilitas tanah berbanding terbalik dengan kandungan liat tanah. Semakin tinggi liat semakin rendah laju permeabilitas tanah. Permeabilitas yang rendah mengakibatkan rendahnya laju masuknya air dari permukaan ke dalam profil tanah atau dikenal dengan infiltrasi. Jika laju curah hujan melebihi laju infltrasi, maka akan terjadi aliran permukaan atau runoff. Aliran permukaan ini merupakan awal terjadinya erosi. Oleh sebab itu berdasarkan permeabilitas tanah maka dapat disimpulkan bahwa kemungkinan tanah terserosi di bawah lahan semak belukar lebih tinggi di bawah penggunaan lahan kebun campuran dan hutan.

\section{Indeks Plastisitas}

Gambar 5 melukiskan secara umum indeks plastisitas tanah pada lapuisan permukaan kurang plastis dari lapisan di bawahnya. Nilai indeks plastisitas suatu tanah dipengaruhi oleh tekstur, khususnya kandungan liat, dan BO tanah. Rendahnya indeks plastisitas tanah pada lapisan permukaan $(0-20 \mathrm{~cm})$ disebabkan oleh tingginya BO tanah di lapisan ini. Bahan organic dapat menurunkan plastisitas tanah, karena BO mampu memodifikasi pengaruh liat dalam suatu tanah. Bahan organic mampu mengikat butir liat membentuk aggregate yang tidak plastis seperti partikel liat tunggal (Oades, 1984). Dengan demikian, semakin tinggi kandungan BO suatu tanah maka semakin rendah indeks plastisitasnya (Hillel, 1982).

Selanjutnya terlihat adanya kecendrungan peningkatan indeks plastisitas tanah dari lahan hutan ke lahan dengan kebun campuran dan semak belukar. Perbedaan ini sangat ditentukan oleh tekstur, terutama kandungan liat suatu tanah. Liat mempunyai kemampuan menjerap air, karena sebagian liat, terutama yang berukuran $\triangleleft \mu \mathrm{m}$, merupakan koloid yang mempunyai muatan. Akan tetapi, tingginya prosentase liat pada lahan di bawah semak belukar dimodifikasi perannya oleh kandungan BO tanahnya yang tinggi. Dengan demikian, prosentase liat yang sangat tinggi antara semak belukar dengan 


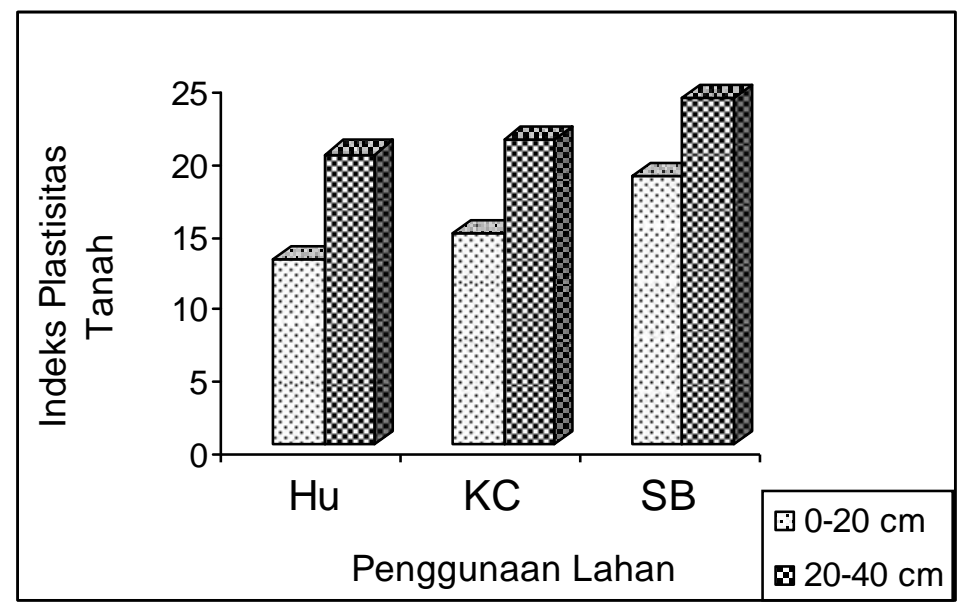

Gambar 5. Indeks plastisitas tanah beberapa penggunaan lahan di Bukik Gajabuih G. Gadut Padang

dua lahan lainnya tidak memberikan perbedaan indeks plastisitas yang besar.

\section{G. SIMPULAN}

Dari hasil survai dan analisis laboratorium yang dilakukan terhadap tanah pada beberapa penggunaan lahan di daerah Bukik Gajabuih kawasan hutan hujan tropik G. Gadut Padang, dapat diambil kesimpulan bahwa:

1. Adanya perbedaan sifat fisika tanah seperti tekstur, BV, kandungan bahan organic, permeabilitas pada setiap penggunaan lahan. Pada penggunaan lahan yang sama terdapat perbedaan sifat fisika antara lapisan tanah atas (0$20 \mathrm{~cm})$ dengan lapisan tanah bawah $(20$ $40 \mathrm{~cm}$ )

2. Tekstur tanah berkisar dari liat (Semak Belukar) sampai lempung berdebu (Hutan dan Kebun Campuran) pada kedua lapisan tanah.

3. Kandungan bahan organic tanah meningkat dari $5.3 \%$ menjadi $7.3 \%$ dan $8.2 \%$ pada lapisan $0-20 \mathrm{~cm}$, tetapi menurun dari $4.0 \%$ menjadi $3.4 \%$ dan $3.4 \%$ pada lapisan $20-40 \mathrm{~cm}$ secara berturut-turut untuk hutan, kebun campuran, dan semak belukar.

4. Nilai BV tanah menurun dari $0.88 \mathrm{gcm}^{-3}$ menjadi $0.72 \mathrm{gcm}^{-3}$ dan $0.69 \mathrm{gcm}^{-3}$ pada lapisan $0-20 \mathrm{~cm}$ dan dari $1.04 \mathrm{gcm}^{-3}$ menjadi $0.81 \mathrm{gcm}^{-3}$ dan $0.79 \mathrm{gcm}^{-3}$ pada lapisan $20-40 \mathrm{~cm}$ secara berturut-turut untuk hutan, kebun campuran, dan semak belukar.

5. Laju permeabilitas tanah menurun dari $36.1 \mathrm{~cm} \mathrm{jam}^{-1}$ menjadi $25.1 \mathrm{~cm} \mathrm{jam}^{-1}$ dan $5.4 \mathrm{~cm} \mathrm{jam}^{-1}$ pada lapisan $0-20 \mathrm{~cm}$ dan dari $34.1 \mathrm{~cm} \mathrm{jam}^{-1}$ menjadi $10 \mathrm{~cm}$ $\mathrm{jam}^{-1}$ dan $1.7 \mathrm{~cm} \mathrm{jam}^{-1}$ pada lapisan 20$40 \mathrm{~cm}$ secara berturut-turut untuk hutan, kebun campuran, dan semak belukar.

6. Indeks plastisitas tanah meningkat dari 12.7 menjadi 14.5 dan 18.6 pada lapisan 0-20 $\mathrm{cm}$ dan dari 20.1 menjadi $21.1 \mathrm{dan}$ 24 pada lapisan $20-40 \mathrm{~cm}$ secara berturut-turut untuk hutan, kebun campuran, dan semak belukar.

Daftar Pustaka

Aase, J.K. and Pikul., J.L.Jr. 1995. Crop and soil response to long-term tillage practices in the northern Great Plains. Agron. J ., 87(4), 652656.

Amelung, W., Zech, W., Zhang, X., Follett, R.F., Tiessen, H., Knox, E., Flach, K.W. 1998. Carbon, nitrogen, and sulfur pools in particle-size fractions as influenced by climate. Soil Sci. Soc. Am. J ., 62(1), 172-181. 
Anderson, J.M., Flanagan, P.W., Caswell, E., Coleman, D.C., Cuevas, E., Freckman, D.W., Jones, J.A., Lavelle, P., and Vitousek, P. 1989. Biological processes regulating organic matter dynamics in tropical soils. In "Dynamics of Soil Organic Matter in Tropical Ecosystems", edited by D.C.Coleman, J.M.Oades, and G.Uehara., NifTAL Project, Univ. of Hawaii, Honolulu, 97-124.

Arsyad, S. 1976. Pengawetan Tanah dan Air. Departemen Ilmu Tanah Fakultas Pertanian IPB. Bogor.

Arsyad, S. 1982. Konservasi Tanah dan Air. Departemen Ilmu-Ilmu Tanah Pertanian IPB. Bogor..

Arsyad, S. 1989. Pengawetan Tanah dan Air. Departemen Ilmu Tanah Fakultas Pertanian IPB. Bogor.

Asdak, C. 1995. Hidrologi Dan Daerah Aliran Sungai. Gadjah Mada University Press. Yogyakarta.

Bayer, C., Mielniczuk, J., Amado, T.J.C., Martin-Neto, L., and Fernandes, S.V. 2000. Organic matter storage in a sandy clay loam Acrisol affected by tillage and cropping systems in southern Brazil. Soil Till. Res., 54 (1/2), 101-109.

Bowman, R.A., Vigil, M.F., Nielsen, D.C., and Anderson, R.L. 1999. Soil organic matter changes in intensively cropped dryland systems. Soil Sci. Soc. Am. J ., 63(1), 186-191.

Brady, N. C. and Weil, R.R. 2002. The nature and properties of soils. $13^{\text {th }}$ Ed., Prentice Hall, Upper Saddle River, 960.

Cadisch, G., de Oliveira, O.C., Cantarutti, R., Carvalho, E., and Urquiaga, S. 1998. The role of legume quality in soil carbon dynamics in Savannah ecosystems. In" Carbon and
Nutrient Dynamics in Natural and Agricultural Tropical E cosystems" edited by L. Bergstrom and H. Kirchmann, Cab International, New York, 319.

Cambardella, C. A. and Elliott, E.T. 1993. Carbon and nitrogen distribution in aggregates from cultivated and native grassland soils. Soil Sci. Soc. Am. J., 57, 1071-1076.

Cambardella, C. A. and Elliott, E.T. 1994). Carbon and nitrogen dynamics of soil organic matter from cultivated grassland soils. Soil Sci. Soc. Am. J ., 58(1), 123-130.

Darmawidjaya, I. 1980. Klasifikasi tanah: Dasar teiri bagi peneliti tanah dan pelaksana pertanian di Indonesia. Balai Penelitian The dan Kina Gambung. 259 hal.

Foth, H.D. 1990. Fundamentals of soil science. $8^{\text {th }}$ Ed. John Wiley and Sons, Inc., New York, 360.

Gee, G. W. and Bauder, J. W. 1986. Particle-size analysis. In "M ethods of Soil Analysis" Part 1 Physical and mineralogical Methods, edited by A.Klute, ASA-SSSA Publ., Madison, 383-412.

Greenland, D.J., Wild, A., and Philips, D. 1992. Organic matter in soils of the tropics: from myth to complex reality. In "Myth and Science of Soils in the Tropics", edited by R.Lal and P.A. Sanchez, Wisconsin, 17-34.

Gregorich, E. G., Ellert, B.H., Drury, C.F., and Liang, B.C. 1996. Fertilization effects on soil organic matter turnover and corn residue $\mathrm{C}$ storage. Soil Sci. Soc. Am. J., 60 (2), 472476.

Hillel, D. 1982. Introduction to soil physics. Academic Press, San Diego, 364. 
House, G.J., Stinner, B.R., Crossley, D.A.Jr., Odum, E.P., and Langdale, G.W. 1984. Nitrogen cycling in conventional and no-tillage in agroecosystems in the Southern Piedmont. J. Soil Water Conserv., 39(3), 194-199.

Hakim, Nurhayati, M.Y. Nyakpa, A.M. Lubis, S.G. Nugroho, M.R. Saul, M.A. Diha, G.B. Hong, dan H.H. Bailey. 1986. Dasar-Dasar IImu Tanah. Universitas Lampung.

Hilmar, F.D. 1991. Prediksi Erosi Dan Penilaian Besarnya Sedimentasi Daerah Aliran Sungai Kuranji Bagian Hulu Kodya Padang. Skripsi Fakultas Pertanian Universitas Andalas. Padang

Jastrow, J. D. 1996. Soil aggregate formation and the accrual of particulate and mineral-associated organic matter. Soil Biol. Biochem., 28(4/5): 665-676.

Lal, R., Kimble, J.M., and Stewart, B.A. 1995c. Towards soil management for mitigating the greenhouse effect. In "Soil Management and Greenhouse Effect", edited by R.Lal, J.Kimble, E.Levine, and B.A Stewart, Lewis Publishers, Boca Raton, 373-381.

Lydersen K. 2002. On farms, a no-till tactic on global warming. (Source: http://www.washingtonpost.com/wp dyn/articles/A553892002Aug23.htm 1).

Lynch, J.M. 1983. Effect of antibiotics on ethylene production by soil microorganisms. Plant and Soil., 7(3), 415-420.

Rahim, S.E. 2000. Pengendalian Erosi Tanah Dalam Rangka Pelestarian Lingkungan Hidup. Bumi Aksara. Jakarta.
Rusman, B. 1999. Konservasi Tanah dan Air. Fakultas Pertanian Universitas Andalas. Padang.

Miller, B.J. 1983. Ultisols. In "Pedogenesis and Soil Taxonomy: II The Soil Orders" edited by L.P.Wilding, N.E.Smack, and G.F. Hall. Elsevier Sci. Publisher B.V. p283-323

Paul, E.A. and Clark, F.E. 1989. Soil microbiology and biochemistry. Academic Press, San Diego, 273.

Paustian, K., Robertson, G.P., and Elliott, E.T. 1995. Management impact on carbon storage and gas fluxes $\left(\mathrm{CO}_{2}\right.$, $\left.\mathrm{CH}_{4}\right)$ in mid-latitude cropland ecosystems. In "Soil Management and Greenhouse Effect", edited by R.Lal, J, Kimble, E.Levine, and B.A.Stewart, Lewis Publishers, Boca Raton, 69-83.

Rasyidin, A. 1994. The method for measuring rates of weathering and soil formation in watershed. Tottory Univ., PhD Disertation, 110 p.

Reicosky, D.C. and Lindstorm, L.J. 1993. Fall tillage method: effect on shortterm carbon dioxide flux from soil. Agron. J., 85 (6), 1237-1248.

Reicosky, D.C. 1995a. Soil variability and carbon dioxide loss after moldboard plowing. Site Specific Management for Agricultural Systems. ASA-CSSA-SSSA Publ., Madison USA, 847-865.

Rusman, B., Yulnafatmawita, and Adrinal. 1993. Ketersediaan Air Tanah Podzolik Merah Kuning Kebun Percobaan Limau Manis Padang.

Saidi, A. 1995. Aliran Permukaan, Sedimentasi Serta Faktor-Faktor Yang Mempengaruhinya Serta Dampaknya Terhadap Degradasi Lahan Di Sub DAS Sumani Solok 
Sumatera Barat. Disertasi Pasca Sarjana Unpad. Bandung.

Seta, A. K. 1987. Konservasi Sumberdaya Tanah dan Air. Kalam Mulia. Jakarta.

Sims, J.R. and Haby, F.A. 1971. Simplified colorimetric determination of soil organic matter. Soil Sci., 112, 137141.

Six, J., Elliott, E.T., Paustian, K., Doran, J.W. 1998. Aggregation and soil organic matter accumulation in cultivated and native grassland soils. Soil Sci. Soc. Am. J., 62(5), 13671377.

So, H.B., Dalal, R.C., Chan, K.Y., Menzies, N.M., and Freebairn, D.M. 1999. Potential of conservation tillage to reduce carbon dioxide emission in Australian soils. Paper presented at the $10^{\text {th }}$ International Soil Conservation Organisation Conference, Purdue University, May 1999, USA.

Suwardjo, H. 1986. Pengaruh panjang lereng dan cara pengelolaan lahan terhadap erosi dan pertumbuhan kedelai. Press Pen Tanah No 6. PPT Bogor.

Syarief, E.S. 1985. Konservasi Tanah dan Air. Pustaka Buana.

Tiessen, H., Chacon, P., and Cuevas, E. 1994. Phosphorus and nitrogen status in soils and vegetation along a toposequence of dystrophic rainforests on the upper Rio Negro. Oecologia., $99(1 / 2), 145-150$.

Veldkamp, E. 1994. Organic carbon turnover in three tropical soils under pasture after deforestation. Soil Sci. Soc. Am. J ., 58 (1), 175-180.

Voorhees, W.B. 2001. The $5^{\text {th }}$ conference of the international soil tillage research organization. Soil \& Tillage Research., 61, 1-2.

Wakatsuki, T., Saidi, A. and Rasyidin, A. 1986. Soil in topsequence of the gunung Gadut tropical rainforest, West Sumatra. South East Asian Studies 24(3):243-262

Wander, M.M., Bidart, M.G., and Aref, S. 1998. Tillage impacts on depth distribution of total and particulate organic matter in three Illinois soils. Soil Sci. Soc. Am. J., 62 (6), 17041711.

Yulnafatmawita. 1995. Sebaran Bahan Organik dan Kepadatan Tanah Kebun Percobaan Fakultas Pertanian Universitas Andalas Limau Manis Padang. Laporan Penelitian SPP/DPP Unand.

Emerson, W.W. (1967). A classification of soil aggregates based on their coherence in water. Aust. J. Soil Res. 5, 47-57.

Yulnafatmawita, I., So, H.B., Menzies, N.W., and Dalal, R.C. 2000. The influence of organic matter on soil structural stability and $\mathrm{CO}_{2}$ release during cultivation. Proceedings of (abstract of) The Postgraduate Conference University of Queensland, October 2000, Gatton, Queensland, Australia,

Yulnafatmawita, I., So, H.B., Menzies, N.W., and Dalal, R.C. 2002. The influence of organic matter on soil structural stability and $\mathrm{CO}_{2}$ release following physical disruption. Proceedings of (extended abstract of) The Australian Society of Soil Science Incorporated (ASSSI) Conference, 2-6 December 2002, Perth, Western Australia, Australia, p260-261.

Yulnafatmawita, So, H.B., Dalal, R.C., and Menzies, N.W. 2003. $\mathrm{CO}_{2}$ Release from Two Contrasting Soils under 
Controlled (Glasshouse) Condition. Proceedings The $16^{\text {th }}$ Triennial International Soil Tillage Research Organisation (ISTRO) Conference, 13-18 July 2003, Brisbane, Queensland, Australia. p1403-1407

Yulnafatmawita, So, H.B., Dalal, R.C., and Menzies, N.W. 2003. $\mathrm{CO}_{2}$ emission from different aggregfate size fractions following physical disruption: Implication for tillage practices. Proceedings The $16^{\text {th }}$ Triennial ISTRO Conference, 13-18 July 2003, Brisbane, Queensland, Australia. p1396-1402
Yulnafatmawita. 2005. Hubungan antara kandungan bahan organic dan stabilitas aggregate tanah akibat perubahan penggunaan lahan. Prosiding Seminar Tahunan BKS-PTN 25-27 April 2005 di Universitas Jambi. 